\title{
Optimized transformation, overexpression and purification of S100A10
}

\author{
Xiaolin Yan ${ }^{1,2}$, Marie-France Lebel-Beaucage ${ }^{3}$, Samuel Tremblay ${ }^{1,2}$, Line Cantin,2 ${ }^{1,}$ Gary S Shaw $^{4}$ \& Elodie Boisselier*,1,2
}

\section{ABSTRACT}

As a member of the $S 100$ protein family, S100A10, has already been purified. However, its purity, or even yield, have often not beenreported in the literature. To facilitate future biophysical experiments with S100A10, we aimed to obtain it at a purity of at least $95 \%$ in a reasonably large amount. Here, we report optimized conditions for the transformation, overexpression and purification of the protein. We obtained a purity of $97 \%$ and performed stability studies by circular dichroism. Our data confirmed that the S100A10 obtained is suitable for experiments to be performed at room temperature up to several days.

\section{METHOD SUMMARY}

The GST-S100A10 gene carried by the pGEX-6P-1 vector was overexpressed in transformed Escherichia coli and purified by glutathione $S$-transferase (GST) affinity chromatography. The GST tag was cleaved by PreScission protease, excess glutathione was removed by centrifugal filtration and buffer exchange and the GST tag removed by a second GST affinity chromatography. S100A10 was identified by LC/MS-MS and the stability of the secondary structure was analyzed by circular dichroism at different temperatures.

\section{KEYWORDS}

GST • overexpression - purification -S100A10 - transformation

'Department of Ophthalmology, Faculty of Medicine, Université Laval, Quebec, QC, Canada; ${ }^{2} \mathrm{CUO}$-Recherche, Centre de Recherche du CHU de Québec, Hôpital du Saint-Sacrement, CHU de Québec, Quebec, QC, Canada; ${ }^{3}$ Departement of Chemistry, Biochemistry \& Physics, Faculty of Sciences, Université du Québec à TroisRivières, Quebec, QC, Canada; ${ }^{4}$ Departement of Biochemistry, Schulich School of Medicine \& Dentistry, University of Western Ontario, London, ON, Canada; ${ }^{*}$ Author for correspondence: Tel.: +1 4186827511 ext. 84429; Elodie. Boisselier@fmed.ulaval.ca

BioTechniques 67: 246-248 (November 2019) $10.2144 /$ btn-2019-0081
S100A10 is of great interest because it has different functions using different mechanisms of action [1-3]. For example, S100A10 forms a ternary complex with annexin A2 and AHNAK to act as a platform enabling membrane repair [4]. In addition, the protein forms a heterotetramer with annexin A2 to regulate exocytosis and endocytosis [5]. In addition to its crucial role in breast, stomach and kidney cancer research, S100A10 represents a potential biomolecular marker for early gallbladder cancer diagnostic and therapeutic applications [6].

The purification of a given protein is an essential prerequisite for any biophysical or biochemical study. In the case of S100A10, the retrieved purification publications reported neither yield data nor solubilized protein amounts [4,7-15]. Among these publications, one mentioned a purity degree of S100A10 greater than $90 \%$ [15] and the other reported 95\% [14], but without any specific supporting data. In this work, we address purity and yield in a clear and comprehensive way, aiming for a purity higher than $95 \%$ and a sufficient amount of S100A10 to carry out biophysical studies. Based on previous experimental conditions with the same expression host, we implemented modifications at each step to optimize the published protocol.

The plasmid used for transformation is a pGEX-6P-1 vector containing the GST-S100A10 coding sequence. Five additional amino acids, GPLGS, were added at the beginning of the native S100A10 sequence, initially composed of 97 amino acids. We used $50 \mathrm{ng}$ of the plasmid for transformation into $100 \mu \mathrm{l}$ of commercial Escherichia coli BL21-Codon Plus (DE3)-RIL competent cells (Agilent Technologies, Inc., CA, USA) in a 900- $\mu$ l transformation cell culture medium. After a heat pulse at $42^{\circ} \mathrm{C}$, the bacteria cell culture was incubated at $37^{\circ} \mathrm{C}, 250 \mathrm{rpm}$ for $1 \mathrm{~h}$.

Initially, the heat pulse was set for $20 \mathrm{~s}$, and we tested two different transformation cell culture media, Luria-Bertan
(LB) and super optimal broth with catabolite repression (SOC). The culture with LB medium produced no colonies. The richer medium, SOC, appeared to be appropriate and should be used for transformation of E. coli BL21-Codon Plus (DE3)-RIL competent cells. We also tested different heat pulse durations using the SOC medium and found that $15 \mathrm{~s}, 20 \mathrm{~s}$ and $30 \mathrm{~s}$ produced 608,700 and 395 colonies, respectively (Figure 1A). While the 20-s heat pulse leads to the most colonies, 30 s would be suitable if a single individualized colony is needed from the agar plate.

After $1 \mathrm{~h}$ of incubation, $100 \mu \mathrm{l}$ of bacteria cell culture was spread on a LB ampicillin agar plate. Triplicate samples were incubated at $37^{\circ} \mathrm{C}$ overnight. Three colonies were chosen from each bacteria preculture, each were incubated in a $4 \mathrm{ml}$ of 2 Yeast Extract Tryptone (2YT) ampicillin medium at $37^{\circ} \mathrm{C}$ and $250 \mathrm{rpm}$ overnight. The colonies were then subjected to two conditions, with and without induction, leading to six different cell cultures. For each, $200 \mu \mathrm{l}$ of preculture was pooled into $50 \mathrm{ml}$ of LB ampicillin medium, incubated at $37^{\circ} \mathrm{C}$ and $250 \mathrm{rpm}$ until an optical density of $600 \mathrm{~nm}\left(\mathrm{OD}_{600 \mathrm{~nm}}\right)$ of 0.6 to 0.8 . Overexpression was initiated by the addition of $0.5 \mathrm{ml}$ of $100 \mathrm{mM}$ isopropyl $\beta$-D-1-thiogalactopyranoside. After $4 \mathrm{~h}$ of incubation at $37^{\circ} \mathrm{C}$ and $250 \mathrm{rpm}$, each cell culture was centrifuged at $3270 \times \mathrm{g}$ and $4^{\circ} \mathrm{C}$ for $30 \mathrm{~min}$. The cell pellet was subjected to lysozyme in phosphate-buffered saline (PBS; $1 \times)$, followed by three cycles of freeze-thaw and sonication. Lysed cells were centrifuged at $15,000 \times \mathrm{g}$ and $4^{\circ} \mathrm{C}$ for $30 \mathrm{~min}$, supernatants and cell pellets were suspended into PBS (1x) and compared on $12 \%$ SDS-PAGE.

The induction of overexpression at $37^{\circ} \mathrm{C}$ for $4 \mathrm{~h}$ was initiated once the $\mathrm{OD}_{600 \mathrm{~nm}}$ reached $0.6,0.7$ or 0.8 . The highest proportion of GST-S100A10 overexpressed in the supernatant (48\%) was obtained at $\mathrm{OD}_{600 \mathrm{~nm}}=0.8$ (Figure 1B). Also, the total amount of GST-S100A10 overexpressed in this condition is higher than in the two other cases 


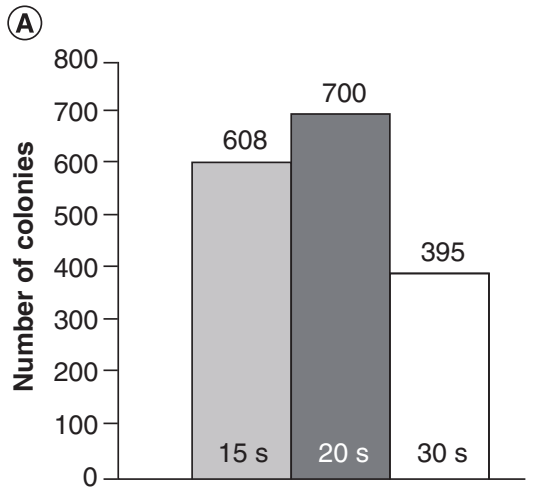

(D)

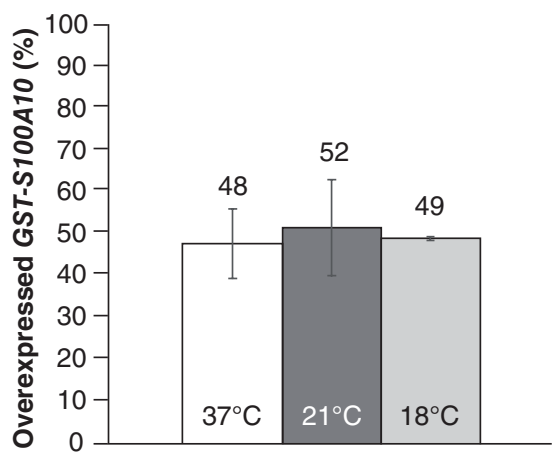

(B)

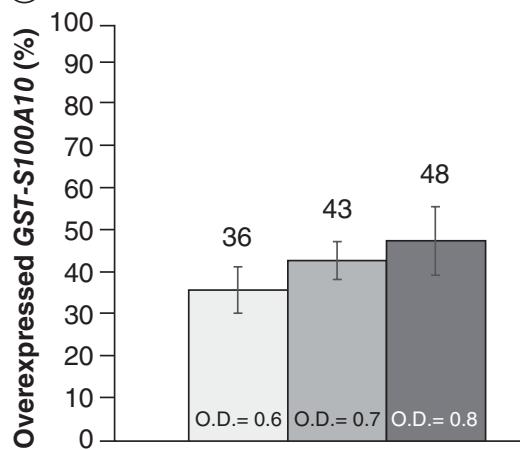

(C)

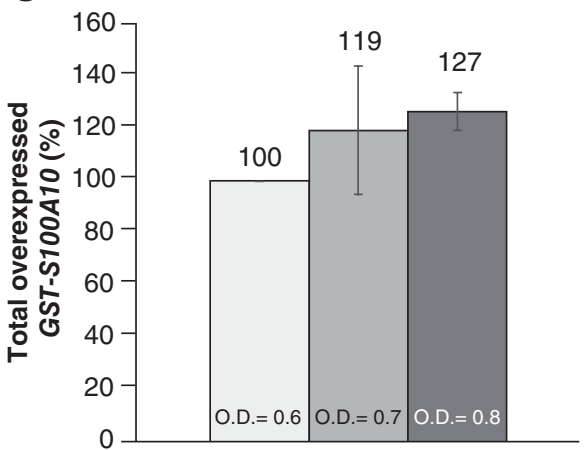

(E)

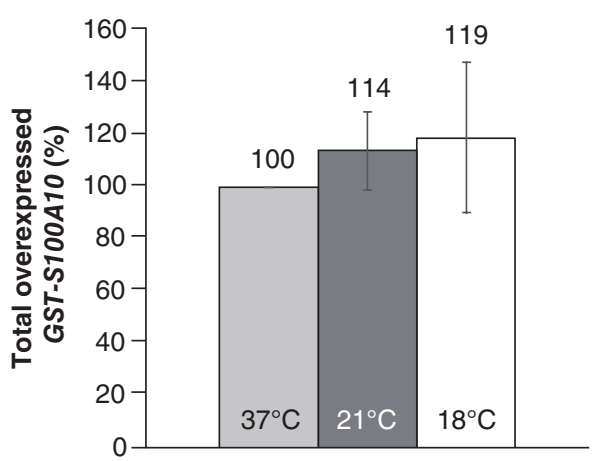

Figure 1. Transformation and overexpression results. (A) Transformation results in a super optimal broth with catabolite repression medium at different heat pulse durations. (B) Percentage of GST-S100A10 overexpressed at $37^{\circ} \mathrm{C}$ in the supernatant with $\mathrm{OD}_{600 \mathrm{~nm}}=0.6,0.7$ and $0.8 ; 100 \%=$ total overexpressed GST-S100A10 at different conditions. (C) Percentage of total GST-S100A10 overexpressed at $37^{\circ} \mathrm{C}$ and $O D_{600 \mathrm{~nm}}=0.6,0.7$ and $0.8 ; 100 \%=$ total overexpressed GST-S100A10 at $37^{\circ} \mathrm{C}$ and $\mathrm{OD}_{600 \mathrm{~nm}}=0.6$. (D) Percentage of GST-S100A10 in the supernatant overexpressed at $O D_{600 \mathrm{~nm}}=0.8$ and $37^{\circ} \mathrm{C}, 21^{\circ} \mathrm{C}$ and $18^{\circ} \mathrm{C} ; 100 \%=$ total overexpressed GST-S100A10 at different conditions. (E) Percentage of total GST-S100A10 overexpressed at OD $600 \mathrm{~nm}=0.8$ and $37^{\circ} \mathrm{C}$, $21^{\circ} \mathrm{C}$ and $18^{\circ} \mathrm{C}, 100 \%=$ total overexpressed $G S T-S 100 A 10$ at $37^{\circ} \mathrm{C}$ and $\mathrm{OD}_{600 \mathrm{~nm}}=0.8$.

(Figure 1C). Indeed, starting the induction with IPTG at $\mathrm{OD}_{600 \mathrm{~nm}}=0.8$ allows the largest amount of soluble GST-S100A10 to be obtained.

In parallel, at $\mathrm{OD}_{600 \mathrm{~nm}}=0.8$, the induction of overexpression was started at either 21 or $18^{\circ} \mathrm{C}$ for $16 \mathrm{~h}$. Similar results were obtained at $21^{\circ} \mathrm{C}(52 \%), 18^{\circ} \mathrm{C}(49 \%)$ and $37^{\circ} \mathrm{C}(48 \%)$ (Figure 1D). However, the total amount of GST-S100A10 overexpressed at 21 and $18^{\circ} \mathrm{C}$ was higher than at $37^{\circ} \mathrm{C}$ (Figure 1E). These results show that a lower temperature favors solubility, probably due to a better recombinant protein structure formation [16].

All precultures showing overexpression of GST-S100A10 were aliquoted in a glycerol solution and frozen at $-80^{\circ} \mathrm{C}$.

GST-S100A10 from bacterial supernatant was first purified using GST affinity chromatography at $4^{\circ} \mathrm{C}$. Eluted fractions were collected and deposited on $12 \%$ SDS-PAGE. Fractions containing GST-S100A10 were mixed together, and the buffer was exchanged with centrifugal filtration before cleaving the GST. One buffer exchange was tested directly with PreScission protease (PSP) cleavage buffer, and another with a $\mathrm{pH} 9.5$ Tris and $\mathrm{NaCl}$ buffer followed by PSP cleavage buffer. After the 2 -h cleavage at $4^{\circ} \mathrm{C}, \mathrm{S} 100 \mathrm{~A} 10$ was purified using different chromatographic conditions: either i) a second and a third GST affinity chromatography; ii) a second GST affinity chromatography and a third ion-exchange chromatography; or iii) only a second GST affinity chromatography. Eluted fractions were collected and verified on $17 \%$ SDS-PAGE (Figure $2 \mathrm{~A}$ ), and the protein purity was analyzed with ImageJ. The highest purity $(97 \%)$ was obtained using the buffer-exchange centrifugal filtration with a $\mathrm{pH} 9.5$ Tris and $\mathrm{NaCl}$ buffer and PSP cleavage buffer, followed by a second affinity chromatography. Indeed, a $\mathrm{pH}$ higher than 8 inhibits the binding of reduced glutathione to GST, while $\mathrm{NaCl}$ increases the ionic strength of the solution to weaken the ionic binding between the proteins (instructions 71-5016-96 AM - GSTrap ${ }^{\mathrm{TM}}$ FF, $1 \mathrm{ml}$ and $5 \mathrm{ml}$ ). These conditions help to remove most of the reduced glutathione during centrifugal filtration, and GST is captured successfully by the second-affinity chromatography. This method also exhibits a relatively high yield of 12.8-mg S100A10 per liter of bacteria culture, which was determined by UV-visible spectroscopy.

The SDS-PAGE gel containing S100A10 was analyzed by LC/MS-MS (Proteomics Platform, Centre de Recherche du CHU de Québec, QC, Canada). It was identified as $5100 \mathrm{~A} 10$ with a $100 \%$ probability. Purified protein samples were kept at four different temperatures: $4,20,-20$ or $-80^{\circ} \mathrm{C}$. Protein stability was analyzed by circular dichroism at $4^{\circ} \mathrm{C}$ in triplicate at day $0,1,2$, $7,15,30$ and 60 . The different temperatures on different days were all compared with day 0 , until day 60 (Figure 2B). No significant difference in the samples' spectra 
(A)

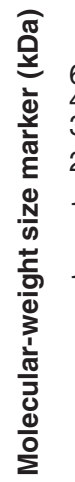

(B)

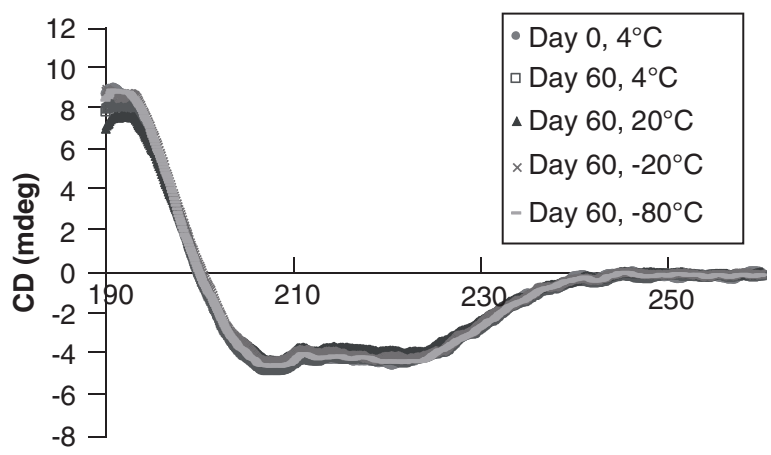

Figure 2. (A) S100A10 purification on $17 \%$ SDS-PAGE: i) after a buffer exchange with PreScission protease (PSP) cleavage buffer, then with a second GST affinity chromatography, and a third GST affinity chromatography, ii) after a buffer exchange with PSP cleavage buffer, then with a second GST affinity chromatography, and a third ion-exchange chromatography, or iii) after a buffer exchange and a second GST affinity chromatography. (B) Analysis of stability: circular dichroism spectra of S100A10 stored at different temperatures for 60 days compared with spectra at $4^{\circ} \mathrm{C}$ on day 0 .

was noted, demonstrating the stability of S100A10 at all temperatures tested. Therefore, the protein can be stored for at least 60 days, allowing researchers to perform biophysical experiments at room temperature.

\section{FUTURE PERSPECTIVE}

The obtention of purified S100A10 protein will allow for future biophysical studies, in particular those aiming to describe its membrane binding. Conditions to modify its binding or leading to its loss of function can be investigated. These studies will contribute to determining the role of S100A10 in membrane repair and possibly additional functions.

\section{AUTHOR CONTRIBUTIONS}

$X Y$ and EB prepared the manuscript. EB designed the study. XY, LC and GSS contributed to the design of the study. $X Y$ performed plasmid transformation, protein overexpression, protein purification and protein stability analysis. MFLB and ST contributed to protein purification. $X Y$ analyzed the data. All the authors read and approved the final version of the manuscript.

\section{FINANCIAL \& COMPLETING INTERESTS DISCLOSURE}

The authors are indebted to the Natural Sciences and Engineering Research Council of Canada (NSERC, Ottawa, Canada), the Eye Disease Foundation, the $\mathrm{CHU}$ de Québec
Foundation for their financial support. EB is a research scholar from the Fonds de recherche du Québec - Santé (FRQS) in partnership with the Antoine Turmel Foundation. $X Y$ is a PhD student that received a scholarship from The Quebec Network for Research on Protein Function, Engineering, and Applications (PROTEO). GSS acknowledges funding from the Canadian Institutes of Health Research (MOP-93520). The authors have no other relevant affiliations or financial involvement with any organization or entity with a financial interest in or financial conflict with the subject matter or materials discussed in the manuscript apart from those disclosed.

The authors would like to thank Enago (www.enago.com) for English language review.

\section{OPEN ACCESS}

This work is licensed under the AttributionNonCommercial-NoDerivatives 4.0 Unported License. To view a copy of this license, visit http://creativecommons.org/ licenses/by-nc-nd/4.0/

\section{REFERENCES}

1. Miwa N, Uebi T, Kawamura S. S100-annexin complexes - biology of conditional association. FEBS J. 275(20), 4945-4955 (2008)

2. Donato R. Intracellular and extracellular roles of $S 100$ proteins. Microsc. Res. Tech. 60(6), 540-551 (2003).

3. Donato R, Cannon BR, Sorci $\mathrm{G}$ et al. Functions of $\mathrm{S} 100$ proteins. Curr. Mol. Med. 13(1), 24-57 (2013)

4. Rezvanpour A, Santamaria-Kisiel L, Shaw GS. The S100A10-annexin A2 complex provides a novel asymmetric platform for membrane repair. J. Biol. Chem. 286(46),
40174-40183 (2011).
5. Nakata T, Sobue K, Hirokawa N. Conformational change and localization of calpactin I complex involved in exocytosis as revealed by quick-freeze, deep-etch electron microscopy and immunocytochemistry. J. Cell Biol. 110(1), 13-25 (1990).

6. Chen $\mathrm{H}, \mathrm{Xu} \mathrm{C}$, Jin Q, Liu Z. S100 protein family in human cancer. Am. J. Cancer Res. 4(2), 89-115 (2014).

7. Santamaria-Kisiel L, Shaw GS. Identification of regions responsible for the open conformation of S100A10 using chimaeric S100A11-S100A10 proteins. Biochem. J. 434(1), 37-48 (2011).

8. De Seranno S, Benaud C, Assard $\mathrm{N}$ et al. Identification of an AHNAK binding motif specific for the Annexin2/S100A10 tetramer. J. Biol. Chem. 281(46), 35030-35038 (2006).

9. Rezvanpour A, Phillips JM, Shaw GS. Design of high-affinity S100-target hybrid proteins. Protein Sci. 18(12), 2528-2536 (2009).

10. Chehab T, Santos NC, Holthenrich A et al. A novel Munc13-4/S100A10/annexin A2 complex promotes Weibel-Palade body exocytosis in endothelial cells. Mol. Biol. Cell. 28(12), 1688-1700 (2017).

11. Jost $M$, Gerke V. Mapping of a regulatory important site for protein kinase $\mathrm{C}$ phosphorylation in the $\mathrm{N}$-terminal domain of annexin II. Biochim. Biophys. Acta 1313(3), 283-289 (1996).

12. Xin D, Zou X, Zuo M, Liu C. The expression and antibody preparation of S100A10 protein. Chin. J. Cell Mol. Immunol. 30(11), 1166-1169 (2014).

13. Rety S, Sopkova J, Renouard M et al. The crystal structure of a complex of p11 with the annexin II N-terminal peptide. Nat. Struct. Biol. 6(1), 89-95 (1999).

14. Streicher WW, Lopez MM, Makhatadze GI. Annexin I and annexin II N-terminal peptides binding to S100 protein family members: specificity and thermodynamic charac terization. Biochemistry 48(12), 2788-2798 (2009).

15. Nazmi AR, Ozorowski G, Pejic M, Whitelegge JP, Gerke $\mathrm{V}$, Luecke $\mathrm{H}$. N-terminal acetylation of annexin A2 is required for S100A10 binding. Biol. Chem. 393(10), 1141-1150 (2012).

16. San-Miguel T, Pérez-Bermúdez $P$, Gavidia I. Production of soluble eukaryotic recombinant proteins in E. coli is favoured in early log-phase cultures induced at low temperature. Springerplus 2(1), 89 (2013). 